\title{
Comparative Evaluation of Different Antimycotoxins for Controlling Mycotoxicosis in Broiler Chickens
}

\author{
Anwaar M. El Nabarawy ${ }^{1 *}$, K. Madian ${ }^{1}$, Iman B. Shaheed ${ }^{2}$ and Wafaa A. Abd El-Ghany ${ }^{1}$ \\ ${ }^{1}$ Poultry Diseases Department, Faculty of Veterinary Medicine, Cairo University, Egypt \\ ${ }^{2}$ Pathology Department, Faculty of Veterinary Medicine, Cairo University, Egypt \\ *Corresponding author's Email: anwaar.elnabarawy@gmail.com; ORCID: 0000-0003-1618-6842
}

Received: 22 Feb. 2020

Accepted: 29 Mar. 2020

\begin{abstract}
Natural contamination of feedstuffs with mycotoxins is considered a major problem affecting the poultry industry in Egypt. Accordingly, this study aimed to compare the ability of different antimycotoxin compounds in the control of mycotoxicosis caused by naturally contaminated diet in broiler chickens. A total of 180 day-old broiler chicks were divided into six groups (30 chicks each group) and kept for a 5-week experimental period. Group 1 was kept as control negative (non mycotoxicated or treated), while group 2 was kept as a positive control (mycotoxicated only). Groups 2-6 were fed ration contaminated with $11 \mathrm{ppb}$ aflatoxins, $3.9 \mathrm{ppb}$ ochratoxins, and $4.2 \mathrm{ppm}$ zearalenone. Groups 3-6 were kept in mycotoxicated ration until 2 weeks of age when clinical signs and lesions were suggestive for mycotoxicosis. Groups 3, 4 and 5 were treated with biological, antioxidant, immunostimulant compounds; respectively. Biological, antioxidants and immunostimulant compounds were given in the drinking water. In group 6, ration was treated with formaldehyde vapor. Performance parameters including body weight, feed consumption and feed conversion rate were recorded weekly. Clinical signs, mortalities and lesions were observed. Serum samples were collected for determination of immunological profile to infectious bursal disease (IBD) virus vaccine. Moreover, liver, kidney and bursa of Fabricius were collected for histopathological examination. Muscles and liver tissue samples were collected for determination of aflatoxins residues. Results revealed significant improvement in performance parameters in treated groups in comparison to non-treated mycotoxicated group, however, antioxidantstreated birds showed the highest performance. The severity of clinical signs and lesions were reduced in the treated chickens compared to non-treated mycotoxicated ones. Significant modulation in immune response toward IBD virus was observed in all treated chickens compared to non-treated mycotoxicated chickens. Histopathological examination of organs of control mycotoxicated birds showed severe degenerative changes which became mild in bursa of Fabricius while returned to normal histological structure in liver and kidney. Residues of aflatoxins in tissues of all groups exceeded the permissible limit with high levels in mycotoxicated control positive group. In conclusion, water treatments with some antimycotoxin agents like biological, antioxidants and immunostimulant compounds greatly counteracted the adverse effect of the naturally contaminated ration with different mycotoxins.
\end{abstract}

Key words: Acids, Antioxidants, Formaldehyde, Immunostimulant, Mycotoxins, Poultry

\section{INTRODUCTION}

Mycotoxins are secondary chemicals, biologically active toxic metabolites of certain toxigenic species of certain fungi that produced under certain environmental conditions of humidity and temperature (Shamsudeen et al., 2013). There are over 200 species of fungus that produce mycotoxins. Aflatoxins, ochratoxins, zearalenone, fumonisins, trichothecenes and other mycotoxins significantly impact the health and productivity of poultry (Murugesan et al., 2015). Mycotoxins-contaminated feed induces severe adverse effects in affected animals including poultry. Birds with mycotoxicosis show reduced feed intake, feed conversion rate (FCR) and productivity, immunosuppression and subsequently increase the susceptibility to different infections (Xue et al., 2010). Even at low concentration, synergistic more toxic and lethal additive action of different mycotoxins types was exert (Boermans and Leung, 2007; Streit et al., 2012). Residues of aflatoxin and ochratoxin have health hazardous effects on the human through consumption of chickens meat and egg (Bryden, 2012).

There are different combined strategies targeting the deactivation of mycotoxins (Jalili et al., 2011). The efficacy of a biological compound containing organic acids, enzymes and yeast extracts was proved in counteracting aflatoxicosis and improving both health and immunity of broiler chickens (Shareef and Omar, 2012). 
Moreover, citric acid supplementation can be used as an additive to degrade aflatoxins in the ration as well as to promote growth performance in young broiler chickens (Salgado-Tránsito et al., 2011). Cultures containing Bacillus subtilis are widely used in the poultry field and showed great efficacy in improving health, performance and immune response of broiler chickens (Bai et al., 2017; Yang et al., 2019). The detoxifying effect of antioxidants such as vitamins $\mathrm{E}$ and $\mathrm{C}$ on some mycotoxins have been studied (Rizzo et al., 1994; Hoehler and Marquardt, 1996; Strasser et al., 2013). It has been found that selenium reduces in vitro toxic effects of T-2 toxin on cultured chicken embryonic chondrocytes (Lin et al., 1994). Some herbal extracts as thymol enhance performance parameters and immunological response to some viral diseases when used to counteract aflatoxicosis in broiler chickens (Manafi et al., 2014). Carvacrol was also effective in ameliorating aflatoxin-induced changes with regard to oxidative stress in broilers (Sridhar et al., 2016). Also, degradation of mycotoxins in contaminated diets using formaldehyde has been reported (Scott, 1998).

Aflatoxin is the extremely toxic type of mycotoxins which is responsible for the carcinogenicity in humans (Anklam et al., 2002; Talebi et al., 2011; Bbosa et al., 2013). According to the International Agency for Research on Cancer (IARC, 2012), aflatoxins belong to group 1 that are carcinogenic for humans. It was recorded that aflatoxins residues were mainly found in the liver and muscle tissues of chickens rather than any organs (Herzallah, 2013; Darwish et al., 2016; Faten et al., 2016). This highlights the importance of monitoring aflatoxins in processed broilers.

Therefore, the present study aimed to investigate and compare the ability of different antimycotoxin agents to counteract mycotoxicosis induced by naturally contaminated diet in broilers.

\section{MATERIALS AND METHODS}

\section{Ethical approval}

The experiments were in accordance with the guidelines laid out by the Ethics Committee of Institutional Animal Care and Use Committee (Vet. CU. IACUC number (10102019093).

\section{Contaminated diet}

Commercial rations specified for broiler chickens were used and analyzed for the levels of contamination with different mycotoxins including aflatoxin, ochratoxin, and zearalenone (AOAC, 1995; FAO, 2003). This naturally contaminated ration was employed to induce mycotoxicosis in broiler chickens.

\section{Antimycotoxin compounds \\ Biological compound}

This compound consists of a group of organic acids including citric, phosphoric, malic, tartaric, aspartic and lactic acid, enzymes as well as dried B. Subtilis fermentation extract. It was added as $0.5 \mathrm{ml} / \mathrm{L}$ of drinking water continually for 5 days during the treatment period ( 3 weeks).

\section{Immunostimulant compound}

Immunostimulant compound contained a group of plant extracts as cat's claw (Uncarcia tomentosa), thymol and carvacrol (Origanum vulgare), in addition to betaine HCL, organic selenomethionine, and mono propylene glycol. It was given in a dose of $0.5 \mathrm{ml} /$ Liter of drinking water continually for 5 days during the treatment period ( 3 weeks).

\section{Antioxidants compound}

A mixture of vitamin $\mathrm{E}$ as well as selenium and vitamin $\mathrm{C}$ were added respectively as $1 \mathrm{ml}$ and $1 \mathrm{gm} /$ /iter of drinking water continually for 5 days during the treatment period (3 weeks).

\section{Formalin fumigation (Chemical type)}

Mycotoxins-contaminated ration was fumigated with $10 \%$ formaldehyde vapor in a tightly sealed container for 12 hours (to avoid escaping of the fumes) and aerated after that for 48 hours before usage. Fumigated ration was replaced mycotoxicated ration of 18 days old chicks.

\section{Chicks and experimental design}

A total of 180, day-old Hubbard broiler chicks were obtained from commercial hatcheries, weighed and randomly divided in a completely randomized experimental design with 6 treatments and 2 replications of 15 chicks in each. Each replicate group was housed in separate conventional thoroughly cleaned and disinfected deep litter pens for 5 weeks. Feed and water were provided ad libitum. Ration was prepared to meet the nutrient requirements of commercial broilers during the starter (1-3 weeks), grower (3-4 weeks) and finisher (4-5 weeks) periods according to NRC (1994). All chickens were vaccinated against Newcastle disease (ND) and infectious bursal disease (IBD) viruses at the $5^{\text {th }}, 12^{\text {th }}$ and $19^{\text {th }}$ day old through eye drop instillation method. The ration was screened for different mycotoxins natural contamination. Group 1 was kept as control negative (non mycotoxicated or treated), while birds in group 2 were kept as control positive (mycotoxicated only) as they fed ration 
contaminated with $11 \mathrm{ppb}$ aflatoxins, $3.9 \mathrm{ppb}$ ochratoxins, and $4.2 \mathrm{ppm}$ zearalenone. Groups 3-6 were mycotoxicated till appearance of suggestive symptom and post-mortem lesions to mycotoxicosis at 18 days old. Birds were fed on rations containing the previous toxins and treated with different antimycotoxins in water. Biological, antioxidants, immunostimulant compounds were given in water for groups 3-5; respectively while formaldehyde fumigated ration was given for group 6 .

\section{Studied parameters}

\section{Health condition}

Birds were kept under observation for 5 weeks for detection of clinical signs, mortalities, and post-mortem gross lesions in all groups.

\section{Performance}

Initial chick's body weight at day of arrival, as well as weekly cumulative body weight, feed consumption and FCR were calculated for all groups as criteria for bird's performance evaluation.

\section{Immunological profile}

Blood samples were collected from the wing vein of 10 birds/group on a weekly basis. The blood was centrifuged at $4000 \mathrm{rpm}$ for $10 \mathrm{~min}$ for serum separation and stored at $-20^{\circ} \mathrm{C}$ for subsequent immunological assessment. The antibodies titers against IBD virus vaccine were measured using Enzyme-Linked Immunosorbent Assay (ELISA) kit (Biochick Veterinary Diagnostic Hounslow, Holland).

\section{Histopathological examination}

Specimens from liver, kidney, and bursa of Fabricius were collected, preserved in $10 \%$ formol saline solution, processed using conventional methods and stained by Haematoxaline and Eosin (H\&E) (Bancroft et al., 1996) for microscopical histopathological examination.

\section{Determination of aflatoxins tissues residues}

Twenty grams of representative samples (muscles and liver were thoroughly ground, mixed with extraction solvent $(70 \%)$ methanol, blended in a steeled blinder for 23 minutes and then filtrated through Whatman \# 1 filter paper. Total aflatoxins in different tissues expressed in nanogram/gram (ng/gm) were estimated using ELISA intended for quantitative detection of mycotoxins (Kensler et al., 2003).

\section{Statistical analysis}

The data were statistically analyzed using the general linear model procedure of the Statistical Analysis System (SAS) software. Overall data were analyzed using one way ANOVA test at a significant level of $\mathrm{p} \leq 0.05$.

\section{RESULTS AND DISCUSSION}

Clinical signs of control positive groups revealed constants, whitish diarrhea, and passage of undigested feed particle and un-uniform growth patterns that were observed from the $2^{\text {nd }}$ week of age. Remarkable improvement in the aforementioned signs was observed in different treated groups. No mortality was observed along the experimental period.

Post-mortem lesions of the sacrificed chickens in mycotoxicated groups showed muscular hemorrhages (Figure 1), pale yellow and friable liver as well as hydropericardium (Figure 2), pale, enlarged and lobulated kidneys as well as atrophy of bursa of Fabricius.

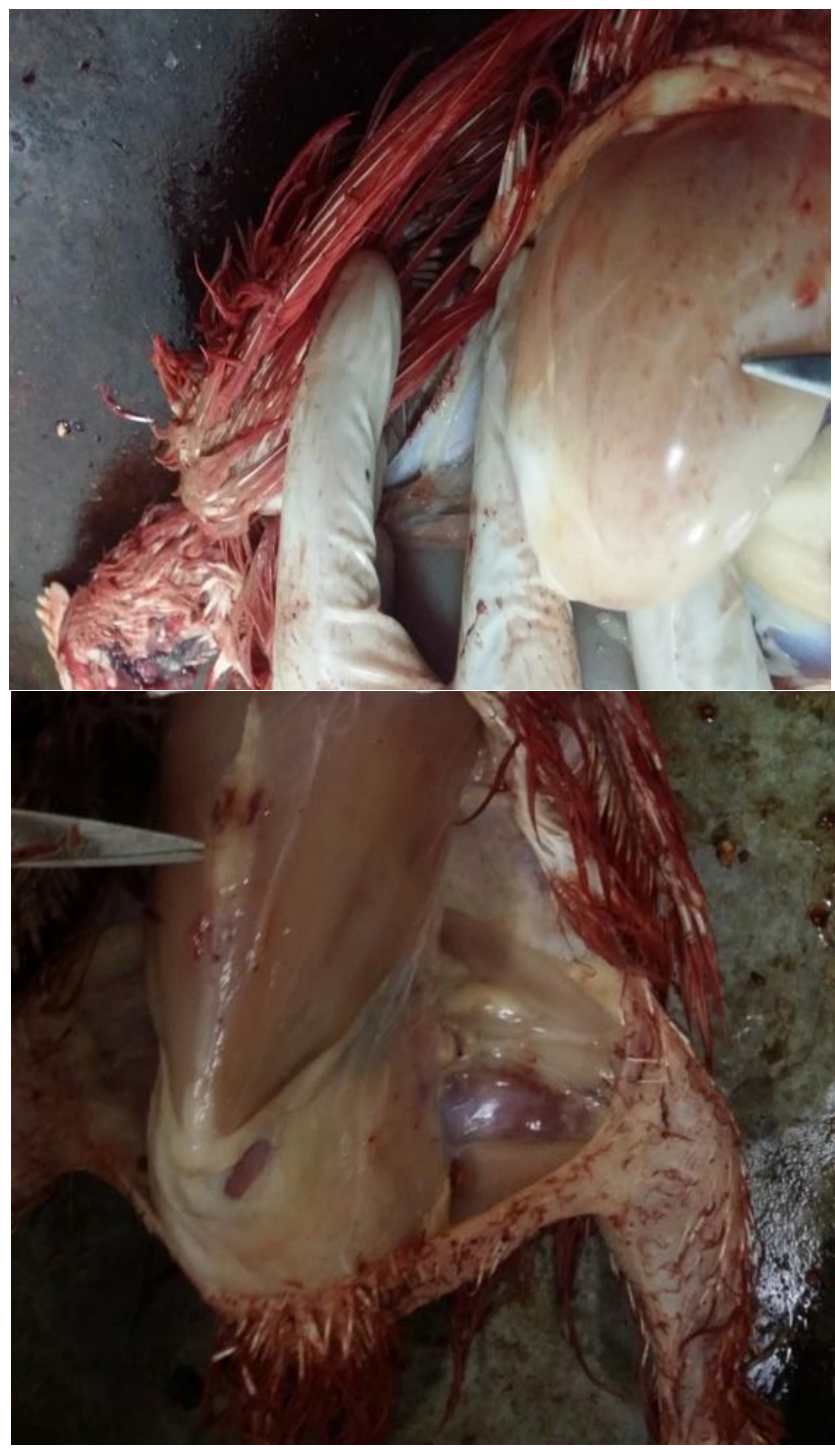

Figure 1. Pitcheal and ecchymotic hemorrhages on the thigh (left) and breast muscles of chicken fed with mycotoxin-contaminated ration. 

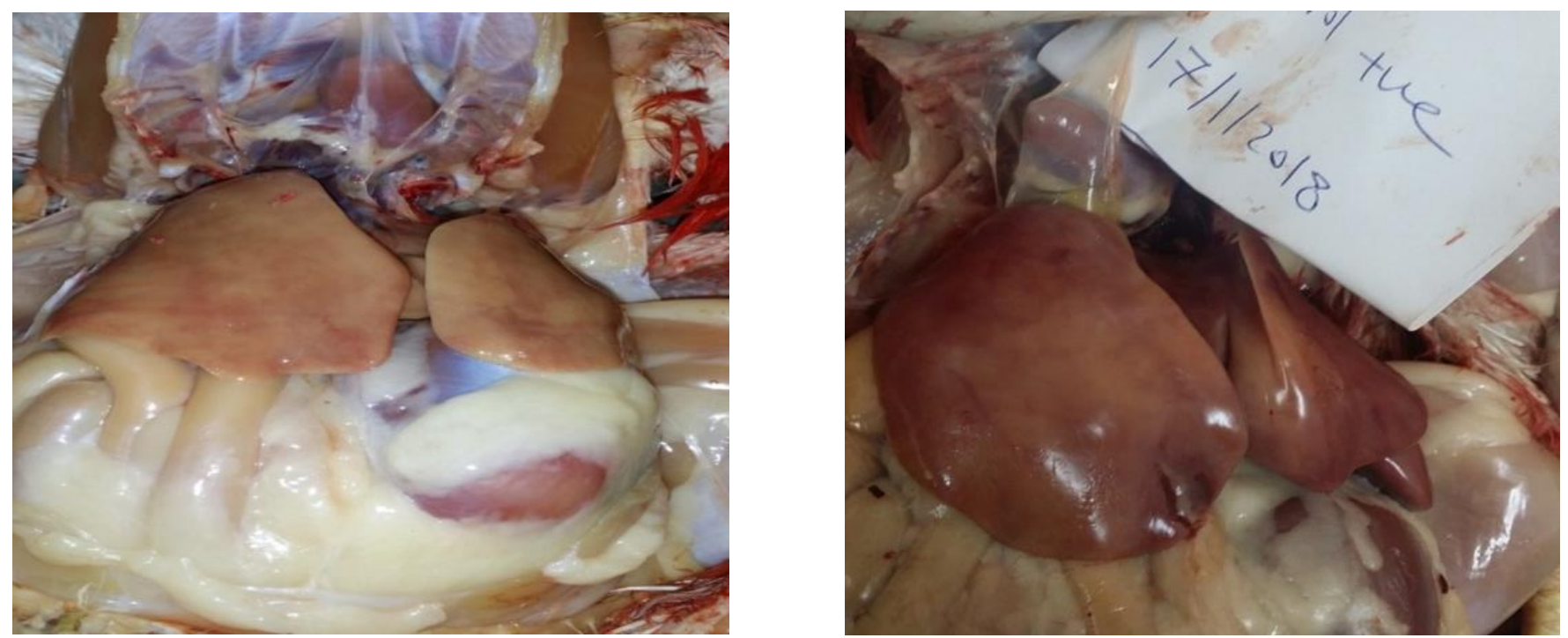

Figure 2. Pale yellow liver with sub-capsular hemorrhages (left) and hydro-pericardium (right) in chicken fed with mycotoxincontaminated ration.

Table 1. Performance parameters in chicken groups fed with mycotoxin-contaminated ration and treated with different methods

\begin{tabular}{|c|c|c|c|c|c|c|}
\hline \multirow{3}{*}{ Groups } & \multicolumn{6}{|c|}{ Weeks post treatment } \\
\hline & \multicolumn{2}{|c|}{$1^{\text {st }}$ week } & \multicolumn{2}{|c|}{$2^{\text {nd }}$ week } & \multicolumn{2}{|c|}{$3^{\text {rd }}$ week } \\
\hline & Body weight (g) & FCR & Body weight (g) & FCR & Body weight (g) & FCR \\
\hline 1 & $687 \pm 109.9^{\mathrm{a}}$ & 1.01 & $11.4 \pm 180.7^{\mathrm{a}}$ & 1.19 & $1740 \pm 219.5^{\mathrm{a}}$ & 0.80 \\
\hline 2 & $601 \pm 133.5^{\mathrm{b}}$ & 1.19 & $868 \pm 153.9^{b}$ & 1.38 & $1140 \pm 180.7^{\mathrm{b}}$ & 1.22 \\
\hline 3 & $741 \pm 114.1^{\mathrm{ad}}$ & 0.83 & $1183 \pm 145.6^{\mathrm{ac}}$ & 0.99 & $1690 \pm 172.8^{\mathrm{a}}$ & 0.82 \\
\hline 4 & $796 \pm 98.9^{\text {cdf }}$ & 0.82 & $1240 \pm 175.5^{\mathrm{ac}}$ & 0.84 & $1815 \pm 272.8^{\mathrm{a}}$ & 0.77 \\
\hline 5 & $659 \pm 95.7^{\mathrm{ae}}$ & 0.95 & $1105 \pm 186.5^{\mathrm{a}}$ & 0.95 & $1735 \pm 361.3^{\mathrm{a}}$ & 0.80 \\
\hline 6 & $757 \pm 85.7^{\text {aef }}$ & 0.83 & $1300 \pm 109.9^{c}$ & 0.81 & $1565 \pm 246.1^{\mathrm{a}}$ & 0.89 \\
\hline
\end{tabular}

Group 1: Control negative (non mycotoxicated and treated). Group 2: Control positive (contaminated ration with 11ppb aflatoxins, 3.9 ppb ochratoxins, and $4.2 \mathrm{ppm}$ zearalenone). Group 3: Mycotoxin contaminated ration treated with a biological compound. Group 4: Mycotoxin contaminated ration treated with an antioxidant compound. Group 5: Mycotoxin contaminated ration treated with an immunostimulant compound. Group 6: Mycotoxin contaminated ration fumigated with formaldehyde. There is a significant difference $(\mathrm{p} \leq 0.05)$ between any two means within the same column have a different superscript letter

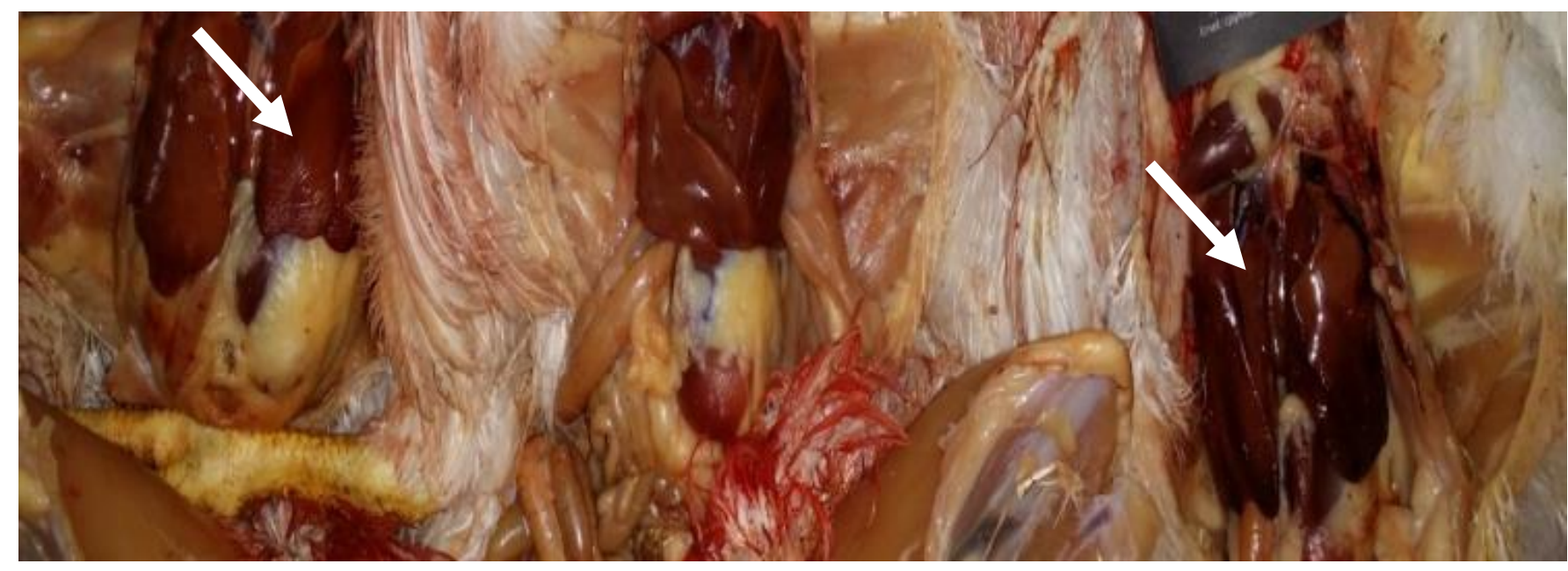

Figure 3. Normal appearance of livers in chicken fed with mycotoxin-contaminated ration and treated with antioxidants 


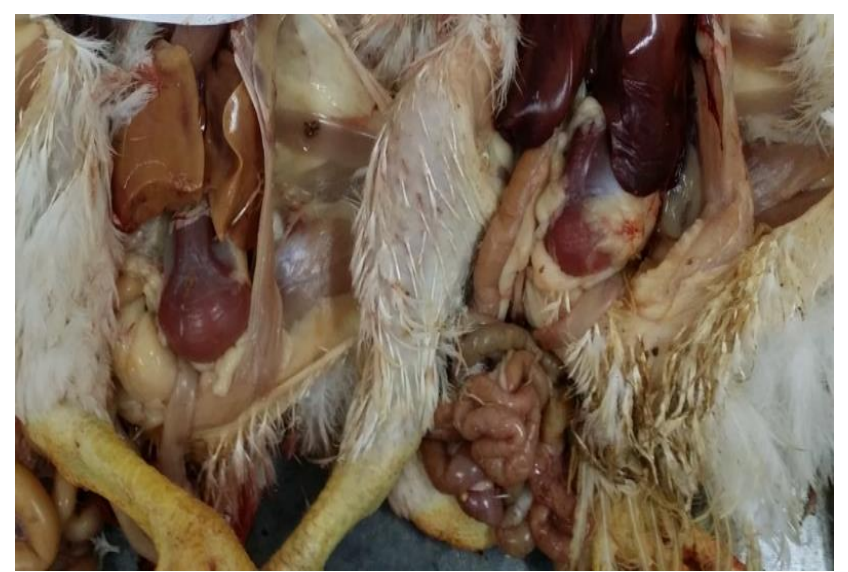

Figure 4. Normal liver of chicken fed with mycotoxincontaminated ration and treated with biological compound (right) compared with pale and friable liver of chicken fed with mycotoxin-contaminated and formaldehyde-fumigated ration (left).

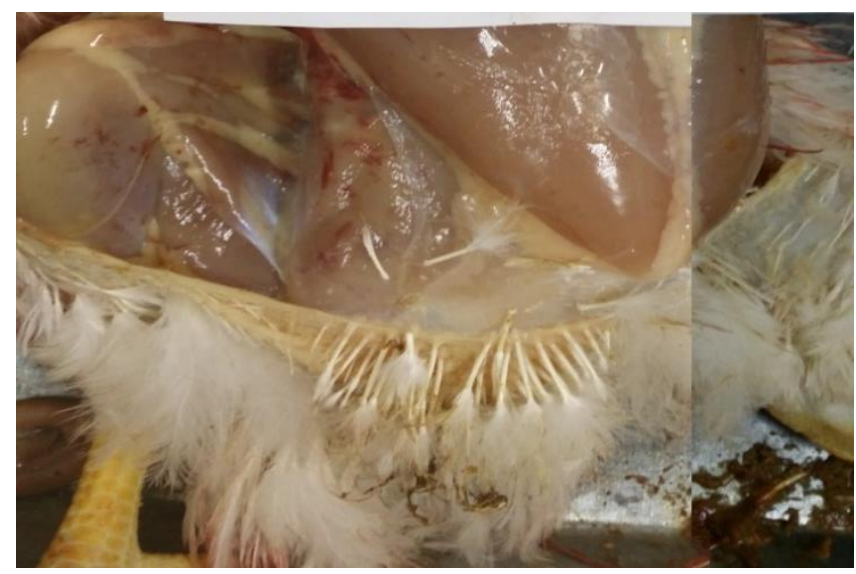

Figure 5. Hemorrhages on muscles of chicken fed with mycotoxin-contaminated and formaldehyde-fumigated diet

Treated groups reflected a pronounced improvement of the previous lesions in different organs (Figures 3 and 4), while such improvement was not remarkable in birds treated with fumigated ration (Figures 4 and 5).

Table 1 shows significant poor performance parameters (body weights and FCR) of control positive mycotoxicated group compared with the control negative one. However, application of different water formulas compounds significantly $(\mathrm{p} \leq 0.05)$ improved performance parameters along the course of treatments ( 3 weeks postintoxication). There is no significant difference among different compounds. Antioxidant treatment of chicks significantly $(\mathrm{p} \leq 0.05)$ improved the performance than formaldehyde, while formaldehyde-treated ration showed the weakest effect of improvement compared with other treatments.
Different types of important mycotoxins can induce damage to cell membranes by increasing lipid peroxidation. Thus, the supplementation of antioxidants to mycotoxicated poultry diet helps to maintain the antioxidant defense mechanism and subsequently increases the poultry production (Fouad et al., 2019). It was recorded that vitamin $\mathrm{E}$ prevented the genotoxicity of zearalenone which may be due to the structural similarity between vitamin $\mathrm{E}$ and zearalenone (Ghe'dira et al., 1998).

The effect of selenium as an antioxidant to reduce the negative effects of mycotoxins was also studied. Selenium can inhibit aflatoxin-DNA binding and adduct formation (Shi et al., 1994). It was found that a mixture of selenium and some vitamins like $\mathrm{E}$ and $\mathrm{C}$ showed antioxidant effects and can protect organs against damage caused by $\mathrm{T} 2$ toxin and deoxynivalenol (Atroshi et al., 1995).

The organic acids present in the used biological compounds also affect the negative one produced by mycotoxins as they improve the growth performance; since acidification increases gastric proteolysis and protein/amino acid digestibility by enhancing digestive enzyme activities (Langhout, 2000). A biological compound containing organic acids, enzymes, and yeast extract proved its efficacy in counteracting the adverse effects of aflatoxins on health, performance, and immunity of broiler chicks (Shareef and Omar, 2012). In laying chickens, B. subtilis improved laying performance, delayed the appearance and concentration of aflatoxin in eggs and also healed zearalenone toxicity in prepubertal gilts when fed diets including zearalenone (Jia et al., 2016). Therefore, $B$. subtilis, as a new biological agent has promising potential in counteracting mycotoxicosis. Addition of some essential oils of herbs also proved an efficacy as an immune-stimulant to counteract the toxic effect of mycotoxins proved efficacy. Ethanolic extract of Thymus vulgaris effectively restored the adverse of aflatoxins in broilers (Manafi et al., 2014).

Some chemicals, such as formaldehyde and urea, can reduce or eliminate the toxic effects of mycotoxin through destructing or modifying toxins (Shantha et al., 1986). Chemical treatment has been used as an effective means for the removal of mycotoxins from contaminated commodities. Chemical detoxifiers inactivate the toxin by modifying its structure molecule to form a less toxic derivative (Samarajeewa et al., 1990). Many common chemicals have been brought to test the effectiveness in detoxification of aflatoxin; one of them is formaldehyde (Suttajit, 1998). The efficiency of chemical detoxification methods of mycotoxins is based on reduction of the toxin 
in the feed and then has been verified by biological assay involving animal model as broiler chicks. Formaldehyde $1 \%$ proved its efficacy as a detoxify agent against aflatoxin and ochratoxin $\mathrm{A}$ in the feed at a laboratory scale (in vitro) as well as in broiler chickens (in vivo) (Lakshmirajam et al., 1984; Anwaar et al., 1998 and 1999). The mechanism by which formaldehyde exerts its detoxifying effect on ochratoxins cannot be stated on the basis of the present study and is still obscure, but it can be speculated that chemical non-toxic complexes with ochratoxins could have been formed as well as ochratoxin molecule possesses both an amide bond and lactone group of ochratoxins molecule, these sites can be attacked during chemical treatment leading to hydrolysis or oxidize the amide bond or lactone group and thereby reduce its toxicity (Jemmali, 1989).

The histopathological results here are listed in Figures (6-8). Microscopical examination of the control positive mycotoxicated group revealed hepatocyte vacuolation of the most cells with cloudy cytoplasm as a result of hydropic degeneration (Figure 6A). The kidneys showed granulation of few numbers of the epithelial lining the tubules (Figure 7A). The bursa of Fabricius showed atrophy of follicles with moderate edema dispersed the follicles from each other and the germinal center of the follicles showed depletion (Figure 8A). Histopathological changes here may be typical to other literature especially those concerning aflatoxicosis (Balachandran and Ramakrishnan, 1987). Group fed on mycotoxin fumigated ration, no histopathological changes could be detected in the liver (Figure 6B) and kidneys (Figure 7B). Meanwhile, the bursa of Fabricius appeared atrophied with vacuolation of the follicles, severe depletion of lymphoid follicles and fibrosis in the interstitial tissues (Figure 8B). Birds treated with a biological compound showed no pathological alterations in the liver (Figure 6C) and kidneys (Figure 7C). Bursa of Fabricius showed normal appearance (Figure 8C). Group treated with immune-stimulant showed normal appearance of the liver (Figure 6D) and kidneys (Figure 7D) without any pathological changes. Similarly, it was observed that carvacrol supplementation (1.0 and $0.5 \%$ ) was efficient in preventing and reducing liver damage and the severity and degree of lesions resulting from aflatoxin toxicity in chickens. Whereas the bursa of Fabricius showed atrophy of the follicles, depletion of germinal centers, increasing of fibrous connective tissue and multiple cyst formation in epithelial lining (Figure 8D). Chickens treated with antioxidants revealed normal appearance of liver (Figure 6E), kidney (Figure 7E) and bursa of Fabricius (Figure 8E) without any pathological changes.

Results presented in Table 2 show the effects of mycotoxins alone and combined with various agents used to alleviate its toxic effects on antibody response of broiler chickens to the IBDV vaccine measured by ELISA. The results showed that ELISA antibody titers of IBDV vaccine were significantly $(\mathrm{p}<0.05)$ reduced in the group of broiler chicks consuming mycotoxins alone in the diet and immunized with IBDV vaccine at 7, 14, and 21 days post-vaccination as compared with the control negative birds. A significant increase $(\mathrm{p}<0.05)$ in ELISA antibody titers was observed in broiler chickens suffering from mycotoxicosis and supplemented with antioxidant, biological antimycotoxins, immune-stimulant, and formaldehyde-fumigated diet, respectively, indicating an improvement in humoral immune response when compared with those in myc otoxicated group without treatment.

Obtained results herein indicated suppression of humoral immune response in the broiler chickens with mycotoxicosis which attributed to histopathological alteration recorded in this study in the bursa of Fabricius which showed atrophy of bursal follicles, moderate edema with germinal center of the follicles showed severe depletion this result is consistent with previous reports of (Karman et al., 2005) who stated that mycotoxins cause aplasia of bursa, thymus and spleen and this finding resulting in a serious deficiency in both humoral and cellular immune response. Also, Yunus et al. (2008) and (2009) reported on the higher correlation between Newcastle disease and mycotoxins as a result of the immune-suppressive nature of mycotoxins.

Hanif and Muhammad (2015) noticed an improvement in the humeral immune response of birds against ND and IBD vaccines titers association with supplementation of mycotoxin deactivator's mannan oligosaccharides, hydrated sodium calcium aluminosilicate, and Lactobacillus acidophilus. Moohaghegh et al. (2017) evaluated the glucomannan on performance and immunity and they indicated that the negative effect mycotoxin on humoral immunity of chickens and liver enzymes activity was ameliorated by supplementing esterified glucomannan. Sawsan (2018) found that treatment of broiler fed on mycotoxin with antimycotoxin compound formulated of L-form bacteria and organic acids in drinking water increase IBDV antibody titers of mycotoxicated chicks at the third weeks of the experimental period. 
The notable improvement in the ELISA antibody titers against IBD vaccine due to the supplementation of different antimycotoxin compounds was reported by Hashemipour et al. (2013) who stated that feed supplementation of broiler chickens with thymol and carvacrol improved the immune response and performance, increased antioxidant activities and digestive enzymes activities, as well as delayed oxidation of lipids. Limaye et al (2018) Stated that selenium possessed an effective antioxidant activity by preventing oxidative liver damage and improving immune status. Awaad et al. (2011) found that the treatment of intoxicated chicks with $\mathrm{L}$ form bacteria in drinking water significantly increased the IBD antibodies titers.

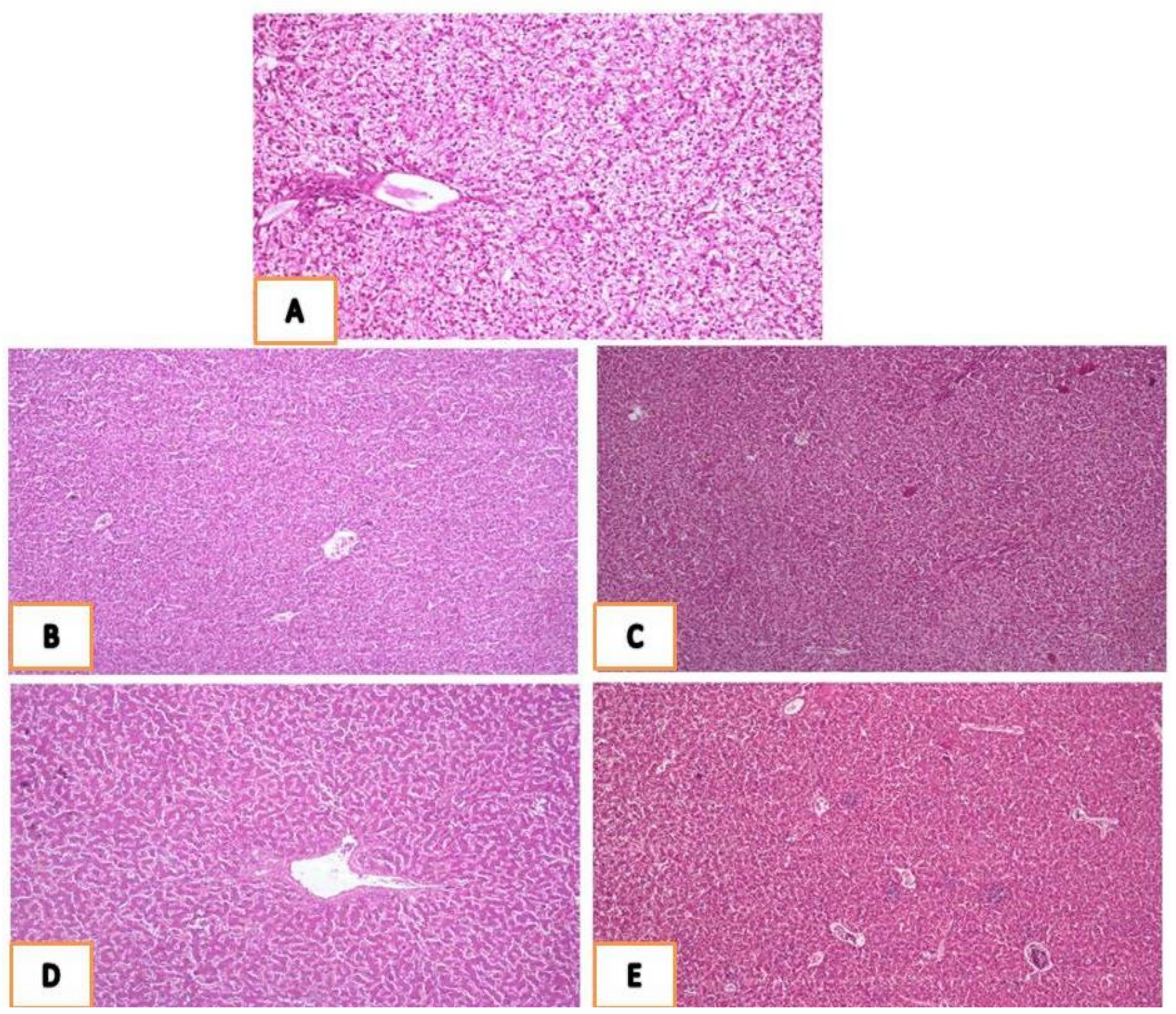

Figure 6. A: Liver of control positive group showing hydropic degeneration in most of hepatocytes (H\&E X100). B: Liver of birds fed with mycotoxin-contaminated and formaldehyde-fumigated ration showing normal appearance (H\&E X100). C: Liver of birds fed with mycotoxin-contaminated ration and treated with biological compound showing normal appearance (H\&E X100). D: Liver of birds fed with mycotoxin-contaminated ration and treated with immunostimulant compound showing normal appearance (H\&E X100). E: Liver of birds fed with mycotoxin-contaminated ration and treated with antioxidants compound showing normal appearance (H\&E X100). 

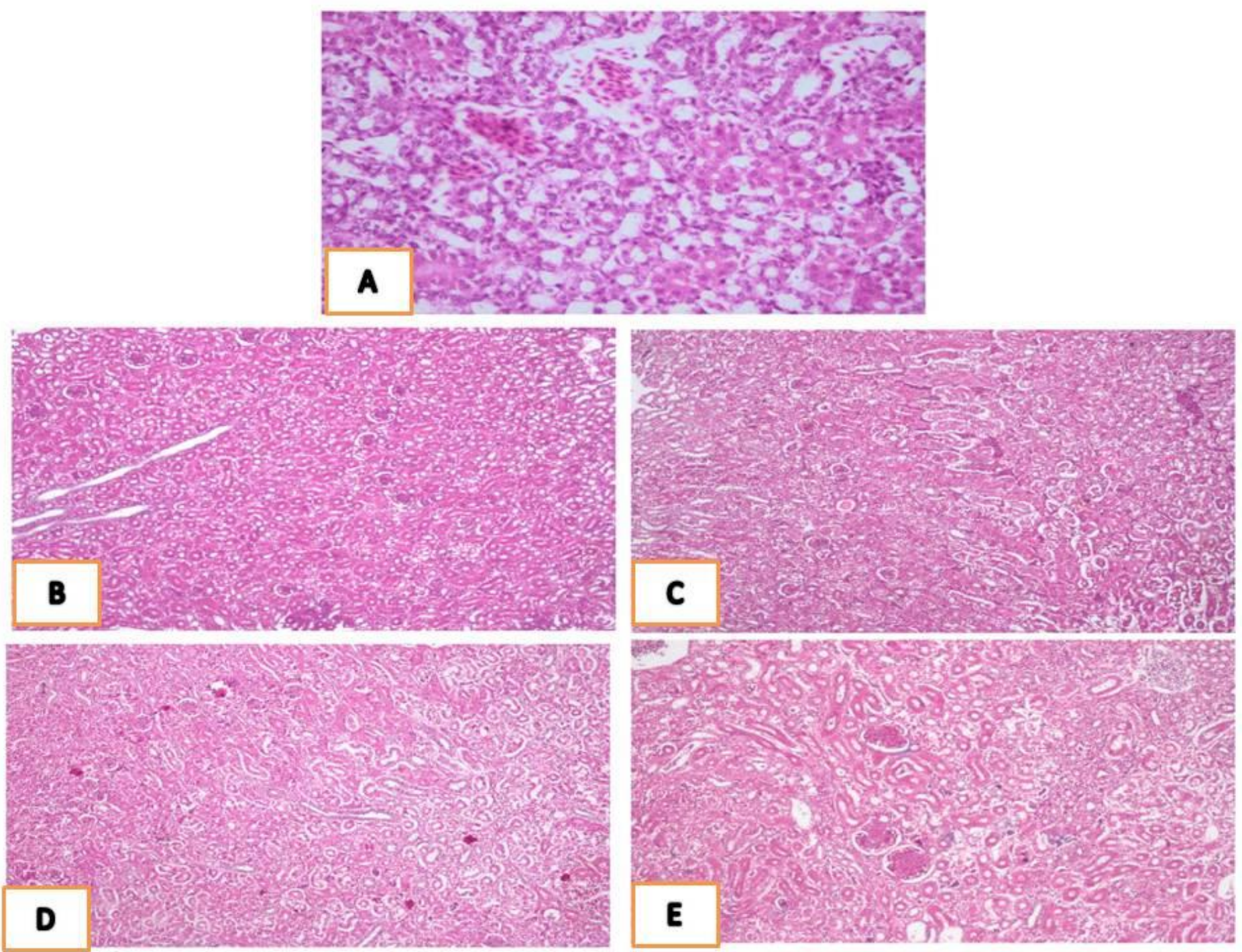

Figure 7. A: Kidney of control positive group showing granulation of few numbers of the epithelial lining the tubules (H\&E 200). B: Kidney of birds fed with mycotoxin-contaminated and formaldehyde-fumigated ration showing normal appearance (H\&E X100). C: Kidney of birds fed with mycotoxin-contaminated ration and treated with biological compound showing normal appearance (H\&E X100).D: Kidney of birds fed with mycotoxin-contaminated ration and treated with immunostimulant compound showing normal appearance (H\&E X100). E: Kidney of birds fed with mycotoxin contaminated ration and treated with antioxidants compound showing normal appearance (H\&E X100). 

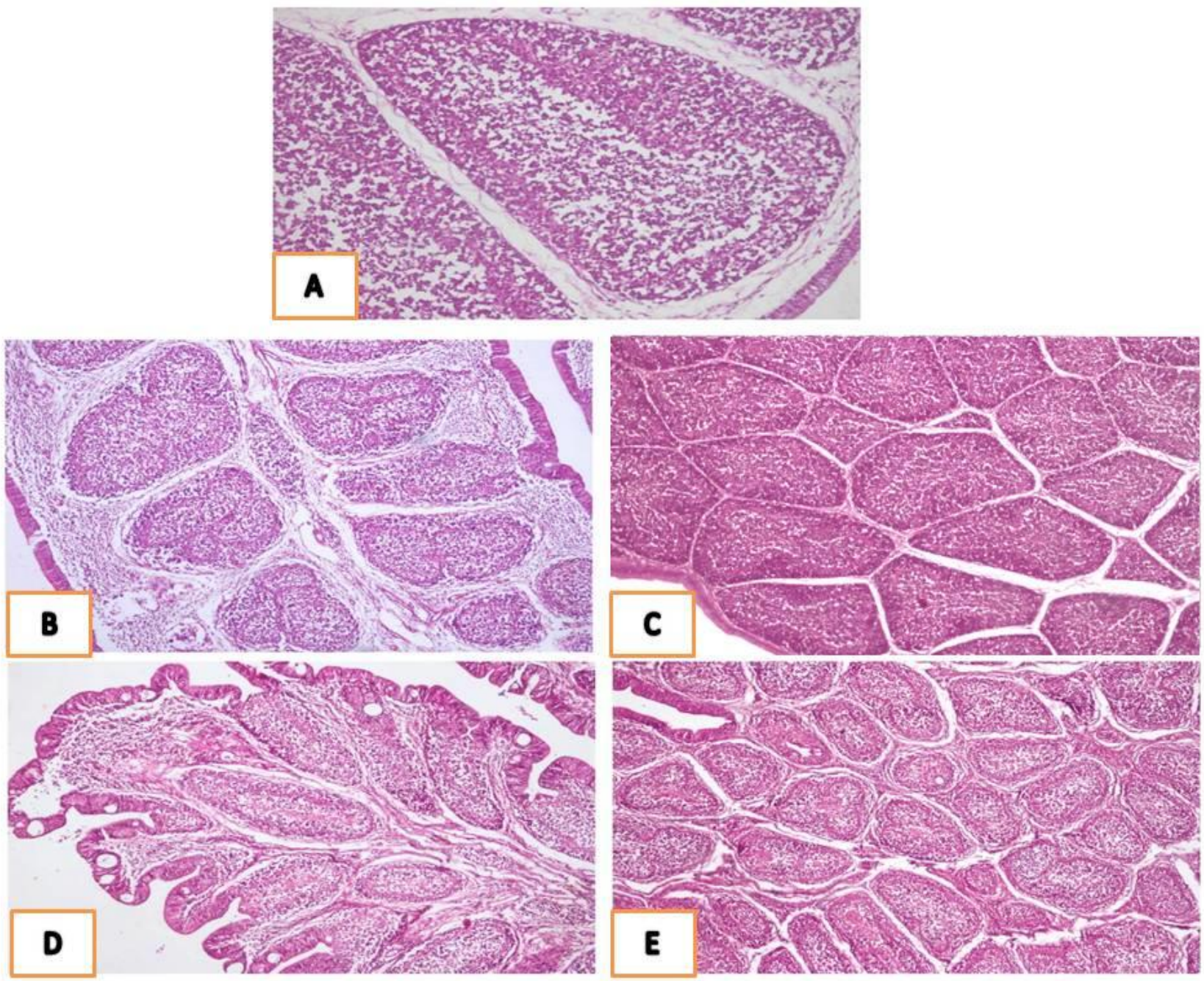

Figure 8. A: Bursa of Fabricius of control positive group showing atrophy of follicles with moderated edema and depletion of germinal center (H\&E 400). B: Bursa of Fabricius of birds fed with mycotoxin-contaminated and formaldehyde-fumigated ration showing atrophy with vacuolation of the follicles; severe depletion of lymphoid follicles and fibrosis in the interstitial tissues (H\&E 100). C: Bursa of Fabricius of birds fed with mycotoxin-contaminated ration and treated with biological compound showing normal appearance (H\&E 100). D: Bursa of Fabricius of birds fed with mycotoxin contaminated ration and treated with immunostimulant compound showing atrophy, depletion, and fibrosis. Notice the multiple cysts in the epithelial lining (H\&E 100). E: Bursa of Fabricius of birds fed with mycotoxin contaminated ration and treated with antioxidants compound showing normal appearance (H\&E X100).

Table 2. Effect of different antimycotoxicosis on $\log _{10}$ titer and ELISA antibody titers against IBDV vaccine in

\begin{tabular}{|c|c|c|c|c|c|c|}
\hline Groups & \multicolumn{6}{|c|}{ Days post vaccination } \\
\hline 1 & $3.03 \pm 0.16^{\mathrm{a}}$ & $1127.73 \pm 416.56^{a}$ & $3.95 \pm 0.11^{\mathrm{a}}$ & $9181.76 \pm 2235.37^{a}$ & $4.05 \pm 0.05^{\mathrm{a}}$ & $11194.44 \pm 1252.93^{a}$ \\
\hline 3 & $2.61 \pm 0.21^{\mathrm{c}}$ & $448.77 \pm 213.06^{\mathrm{c}}$ & $3.25 \pm 0.34^{\mathrm{cd}}$ & $2224.47 \pm 1561.83^{\mathrm{cd}}$ & $4.01 \pm 0.13^{\mathrm{ac}}$ & $10622.81 \pm 2822.07 \mathrm{ac}$ \\
\hline 4 & $3.09 \pm 0.08^{\mathrm{a}}$ & $1251.78 \pm 224.81^{\mathrm{a}}$ & $4.00 \pm 0.03^{\mathrm{a}}$ & $9996.10 \pm 625.46^{\mathrm{a}}$ & $4.05 \pm 0.06^{\mathrm{a}}$ & $11335.03 \pm 1573.27^{\mathrm{a}}$ \\
\hline
\end{tabular}

mycotoxicated broiler chickens at 7,14 and 21 days post-vaccination. Group (1): Control negative (non mycotoxicated and treated) Group (2): Control positive (contaminated ration with 11ppb aflatoxins, $3.9 \mathrm{ppb}$ ochratoxins, and $4.2 \mathrm{ppm}$ zearalenone). Group (3): Mycotoxin contaminated ration treated with a biological compound. Group (4): Mycotoxin contaminated ration treated with an antioxidant compound. Group (5): Mycotoxin contaminated ration treated with an immunostimulant compound. Group (6): Mycotoxin contaminated ration fumigated with formaldehyde.There is a significant difference ( $\mathrm{p} \leq 0.05$ ) between any two means within the same column have a different superscript letter. 
Table 3 reveals the results of total aflatoxin residues in the muscles and liver in different groups using ELISA. The highest concentration of aflatoxins in the muscles was seen in the positive control group, while the lowest one was detected in chickens treated with antioxidant. Aflatoxin concentration in the liver tissues showed its highest level in immune-stimulant treated group and lowest level in that treated with biological compound. Variable frequency of aflatoxin B1 contamination was demonstrated in liver of chickens where $~ 50 \%$ of samples were positive with $3.2 \mu \mathrm{g} / \mathrm{kg}$ maximum mean level in chicken liver samples (Rodríguez-Amaya and Sabino, 2002).

Table 3. Determination of aflatoxin residues using ELISA in broiler muscles and liver tissue samples

\begin{tabular}{lcc}
\hline \multirow{2}{*}{ Groups } & \multicolumn{2}{c}{ Total aflatoxins concentration (ng/g) in tissue } \\
samples
\end{tabular}

\section{CONCLUSION}

It is concluded that an antioxidant (a mixture of selenium, vitamin $\mathrm{E}$ and vitamin $\mathrm{C}$ ) and a biological origin based compound containing B. Subtilis and organic acids and enzymes completely restored the adverse effects of mycotoxicosis on body weight, lesions and histopathological changes in chickens. The biological compound was able to reduced aflatoxin residues in liver tissue samples to the permissible level. Accordingly, it is suggested to use antioxidants and biologically based $B$. Subtilis compounds to effectively control mycotoxicosis resulting from naturally contaminated broiler ration.

\section{DECLARATIONS}

\section{Acknowledgments}

This study was financially supported by the research sector of Cairo University through project titled "Mycotoxicosis, the natural potent and immune- suppressive carcinogen of veterinary and public health concern".

\section{Authors' contributions}

Anwaar M. El-Nabarawy planned the experimental design and contributed to the experimental work, data collection, writing and revision of the manuscript. K. Madian helped in the experimental work and writing of the manuscript. Iman B. Shaheed was concerned with the histopathological section of the manuscript. Wafaa A. Abd El-Ghany contributed to the experimental work and contributed to data collection, writing and revision of the manuscript.

\section{Competing interests}

The authors have no conflict of interest.

\section{REFERENCES}

Anklam E, Stroka J and Boenke A (2002). Acceptance of analytical methods for implementation of EU legislation with a focus on mycotoxins. Food Control, 13: 173-183. DOI: https://doi.org/10.1016/S0956-7135(01)00098-6

Anwaar M El-Nabarawy, Dyab KM, Edris BM, Amra HA and Saad FE (1998). Proceeding to the 5th Scientific Conference of the Egyptian Veterinary Poultry Association, 187- 201.

Anwaar M El-Nabarawy, Ragheb RR, Salem RMT and Nariman A Rahmy (1999). Comparative studies of new methods for controlling ochratoxicosis in broiler chickens. Journal of the Egyptian Veterinary Medical Association, 59: 933- 949.

AOAC (1995). Association of Official Analytical Chemists, Official Methods of Analysis. 16th ed. Method 991.31. Gaithersburg, MD, USA.

Atroshi F, Rizzo A, Biese I, Salonen M, Lindberg LA and Saloniemi H (1995). Effects of feeding T-2 toxin and deoxynivalenol on DNA and GSH contents of brain and spleen of rats supplemented with vitamin $\mathrm{E}$ and $\mathrm{C}$ and selenium combination. Journal of Animal Physiology and Animal Nutrition, 74: 157-164. DOI: https://doi.org/10.1111/j.1439-0396.1995.tb00447.x

Awaad MHH, Attia AM, Abd EL-Ghany WA, Elmenawey M, Ahmed K, Hassan AA, Nada AA and Abdelaleem A (2011). Effect of a specific combination of mannanooligosacharides and B - glucose extracted from yeast cell wall on the health status and growth performance of ochratoxicated broiler chickens. Journal of American Science, 7(3):82-96. Available http://www.jofamericanscience.org/journals/amsci/am0703/10_4872am0703_82_96.pdf

Bai K, Huang Q, Zhang J, He J, Zhang L and Wang T (2017). Supplemental effects of probiotic Bacillus subtilis fmbJ on growth performance, antioxidant capacity, and meat quality of broiler chickens. Poultry Science, 96: 74-82. DOI: https://doi.org/10.3382/ps/pew246

Balachandran C and Ramakrishnan R (1987). An experimental study on the pathology of aflatoxicosis in broiler chicken. Indian Veterinary Journal, 64: 911-914. Available at: https://doi.org/10.1007/BF01839249

Bancroft D, Stevens A and Turner R (1996). Theory and practice of histological techniques. Fourth edition, Churchill Livingstone, Edinburgh, London, Melbourne. DOI: https://trove.nla.gov.au/work/10963990

Bbosa GS, Kitya D, Odda J and Ogwal-Okeng J (2013). Aflatoxins metabolism, effects on epigenetic mechanisms and their role in 
carcinogenesis. Health, 5: 14-34. DOI: http://dx.doi.org/10.4236/health.2013.510A1003

Boermans HJ and Leung MCK (2007). Mycotoxins and the pet food industry: Toxicological evidence and risk assessment. International Journal of Food Microbiology, 119: 95-102. DOI: https://doi.org/10.1016/j.ijfoodmicro.2007.07.063

Bryden WL (2012). Mycotoxin contamination of the feed supply chain: Implications for animal productivity and feed security. Animal Feed Science and Technology, 173: 134-158. DOI: https://doi.org/10.1016/j.anifeedsci.2011.12.014

Darwish WS, El-Bayomi RM, Abdel-Oaty AM and Gad TM (2016). Mold contamination and aflatoxin residues in frozen chicken meat cuts and giblets. Japanese Journal of Veterinary Research, 46: 167-171. DOI: http://hdl.handle.net/2115/62009

FAO, Food and Agriculture Organization of the United Nations (2003). Manuals of Food Quality Control 10. Training in Mycotoxins Analysis. Available at: http://www.fao.org/3/a-t0322e.pdf

Faten SH, Mohammed MM, Mahomud AH, Wafaa MH and Fatma HA (2016). Aflatoxins residues in chicken and turkey tissues. Benha Veterinary Medical Journal, 31 (2): 130-135. DOI: https://dx.doi.org/10.21608/bvmj.2016.31281

Fouad AM, Ruan D, El-Senousey HK, Chen W, Jiang S and Zheng C (2019). Harmful effects and control strategies of aflatoxin B1 produced by Aspergillus flavus and Aspergillus parasiticus strains on poultry: Review. Toxins, 11 (176): 1-21. DOI: https://doi.org/10.3390/toxins11030176

Ghe'dira CL, Zakhama KMA, Ellouz F, Dhouib S, Creppy EE and Bacha H (1998). Induction of a SOS repair system in lysogenic bacteria by zearalenone and its prevention by vitamin E. Chemical and Biological Interaction, 113:15-25. DOI: https://doi.org/10.1016/s0009-2797(98)00013-1

Hanif NQ and Muhammad G (2015). Immunotoxicity of ochratoxin A and role of Trichosporon mycotoxinivorans on the humoral response to infectious viral disease vaccines in broilers. Pakistan Journal of Zoology, 47 (6): 1683-1689. Available at: http://www.zsp.com.pk/pdf47/1683-1689\%20(24)\%20PJZ-2232$15 \% 2030-7-15 \% 202$ nd\%20revised\%20copy\%205-6$15 \% 20$ MANUSCRIPT\%20-\%20revised $\% 202$ nd $\% 20$ s_.pdf

Hashemipour H, Kermanshahi H, Golian A and Veldkamp T (2013). Effect of thymol and carvacrol feed supplementation on performance, antioxidant enzyme activities, fatty acid composition, digestive enzymes activities and immune response in broiler chickens. Poultry Science, 92(8): 2059-2069. DOI: https://doi.org/10.3382/ps.2012-02685

Herzallah SM (2013). Aflatoxin B1 residues in eggs and flesh of laying hens fed aflatoxin B1 contaminated diet. American Journal of Agricultural and Biological Sciences, 8: 156-161. Available at: http://www.thescipub.com/ajabs.toc

Hoehler D and Marquardt R (1996). Influence of vitamins E and C on the toxic effects of Ochratoxin A and T-2 toxin in chicks. Poultry Science, 75: 1508-1515. DOI: https://doi.org/10.3382/ps.0751508

IARC (2012). Overall evaluations of carcinogenicity: An updating of IARC monographs. IARC Monograph Evaluation of Carcinogen. Risks to Human, 100: 51-72. Available at: https://monographs.iarc.fr/wp-content/uploads/2018/06/mono82.pdf

Jalili M, Jinap S and Son R (2011). The effect of chemical treatment on reduction of aflatoxins and ochratoxin a in black and white pepper during washing. Food Additives and Contaminants, 28 (4): 485-493. DOI: https://doi.org/10.1080/19440049.2010.551300

Jemmali M (1989). In Mycotoxin and phycotoxins 88, Natori S, Hashimoto K, and Ueno Y. (Ed), Elsevier Science, Amsterdam, the Netherlands, p., 233- 241.

Jia R, Ma Q, Fan Y, Ji C, Zhang J, Liu T and Zhao L (2016). The toxic effects of combined aflatoxins and zearalenone in naturally contaminated diets on laying performance, egg quality and mycotoxins residues in eggs of layers and the protective effect of
Bacillus subtilis bio-degradation product. Food Chemistry and Toxicology, $90: \quad 142-150 . \quad$ DOI http://doi.org/10.1016/j.fct.2016.02.010

Karman M, Basmacioglu H, Ortatatli M and Oguz H (2005). Evaluation of detoxifying effect of yeast glucomannan on aflatoxicosis in broilers as assessed by gross examination and histopathology. British Poultry Science, $\quad 46: \quad 394-400$.

https://doi.org/10.1080/00071660500124487

Kensler TW, Qian GS, Chen GH and Groopman JD (2003). Translational strategies for cancer prevention in liver. Nature Reviews Cancer, 321-329. DOI: http://doi.org/10.1038/nrc1076

Kumar A, Jindal N, Shukla CL, Asrani R K, Ledoux DR and Rottinghaus GE (2004). Pathological changes in broiler chickens fed ochratoxinA and inoculated with Escherichia coli. Avian Pathology, 33: 413-417. DOI: https://doi.org/10.1080/03079450410001724021

Lakshmirajam S, Reddy VR and Rao PV (1984). Efficiency of selected methods of detoxification of feed infested with aflatoxin. Indian Journal of Animal Sciences, 54: 348-352. Available at: https://www.redalyc.org/pdf/939/93980101.pdf

Langhout P (2000). New additives for broiler chickens. World Poultry, 16 (3): 22-27. Available at: https://www.cabdirect.org/cabdirect/abstract/20001416551

Lin ZH, Li SG, Wu LY, Sun S and Lu QW (1994). Antagonistic effect of Se on the T-2 toxin-induced changes in the ultrastructure and mitochondrial function of cultured chicken embryonic chondrocytes. Journal of Clinical Biochemistry and Nutrition, 17: 119-132. DOI: https://doi.org/10.3164/jcbn.17.119

Limaye A, Roch-ChuiY, Cheng-Chun C, Je-Ruei L and Kuan-Cheng C (2018). Protective and detoxifying effects conferred by dietary selenium and curcumin against AFB1-mediated toxicity in livestock: $\begin{array}{lllll}\text { A Review. Toxins, } 10 & \text { (25): } 1-18 . & \end{array}$ https://dx.doi.org/10.3390\%2Ftoxins10010025

Manafi M, Hedayati M and Yari M (2014). Aflatoxicosis and herbal detoxification: The effectiveness of thyme essence on performance parameters and antibody titers of commercial broilers fed Aflatoxin B1. Research in Zoology, 4 (2): 43-50. DOI: https://10.5923/j.zoology.20140402.02

Moohaghegh A, Chamani M, Shivasad M, Sadighi AAA and Afzali N (2017): Effect of sterified glucomannan on broilers exposed to natural mycotoxin- contaminated diets. Journal of Applied Animal Research, 45(1):285-291. https://doi.org/10.1080/09712119.2016.1174122

Murugesan GR, Ledoux DR, Naehrer K, Berthiller F, Applegate TJ, Grenier B, Phillips TD and Schatzmayr G (2015). Prevalence and effects of mycotoxins on poultry health and performance, and recent development in mycotoxin counteracting strategies. Poultry Science, 94: 1298-1315. DOI: https://doi.org/10.3382/ps/pev075

NRC, National Research Council (1994). Nutrient Requirements of Poultry. 9th ed. National Academy of Sciences, Washington. DOI: https://doi.org/10.17226/2114.

Rizzo AF, Atroshi F, Ahotupa M, Sankari S and Elovaara E (1994). Protective effect of antioxidants against free radical mediated lipid peroxidation induced by DON or T-2 toxin. Zentralbl Veterinarmed, A. $\quad 41: 81-90$. DOI: https://doi.org/10.1111/j.14390442.1994.tb00070.x

Rodríguez-Amaya DB and Sabino M (2002). Mycotoxin research in Brazil: The last decade in review. Brazilian Journal of Microbiology, 33: 1-11. DOI: http://dx.doi.org/10.1590/S1517-83822002000100001

Salgado-Tránsito L, Del Río-García JC, Arjona-Román JL, MorenoMartínez E and Méndez-Albores A (2011). Effect of citric acid supplemented diets on aflatoxin degradation, growth performance and serum parameters in broiler chickens. Archive Medicine Veterinary, 43: 215-222. DOI: http://dx.doi.org/10.4067/S0301732 X2011000300003.

Samarajeewa U, Sen AC, Cohen MD and Wei CI (1990). Detoxification of aflatoxins in foods and feeds by physical and chemical methods. 
El Nabarawy et al., 2020

Journal of Food Protection, 53: 489-501. DOI: https://doi.org/10.4315/0362-028X-53.6.489

SAS Institute (2000). SAS ${ }^{\circledR}$ User's Guide: Statistics. Version \& Edition. SAS Institute Inc., Cary, NC, USA.

Sawsan SM (2018): Evaluation of some anti-mycotoxins drugs in broiler chickens. Ph. D. Thesis, Department of Avian and Rabbit Diseases. Faculty of Veterinary Medicine, Benha University, Egypt.

Scott PM (1998). Industrial and farm detoxification processes for mycotoxins. Veterinary Medicine Review, 149: 543-548. Available at:

https://books.google.com.eg/books?id=9ILUG4fBtp4C\&pg=PA95\&l $\mathrm{pg}=\mathrm{PA} 95 \& \mathrm{dq}=$ Industrial+and+farm+detoxification+processes+for+ mycotoxins.+Veterinary+Medicine+Review, $+149:+543-$ 548.\&source=bl\&ots=hlKUsZGg3Y\&sig=ACfU3U1Nwh2eXxy4HR uOcTIvE5NwVqO4GQ\&hl=en\&sa=X\&

Shamsudeen P, Shrivastava HP, Singh R and Deo C (2013). Effect of chelated and inorganic trace minerals on aflatoxin synthesis in maize. Journal of Poultry Science and Technology, 1 (1): 13-16. Available at: http://www.jakraya.com/journal/jpst

Shantha T, Sreenivasa M, Rati ER and Prema V (1986). Detoxification of groundnut seeds by urea and sunlight. Journal of Food Safety, 7: 225-231. DOI: https://doi.org/10.1111/j.1745-4565.1986.tb00544.x

Shareef A and Omar EKS (2012). Effect of Synertox ${ }^{\circledR}$ on broiler health and performance during aflatoxicosis. Iraqi Journal of Veterinary Sciences, 26: 27-34. Available at: http://citeseerx.ist.psu.edu/viewdoc/download?doi=10.1.1.429.2808 \&rep=rep $1 \&$ type $=$ pdf

Shi CY, Chua SC, Lee HP and Ong CN (1994). Inhibition of aflatoxin B1DNA binding and adduct formation by selenium in rats. Cancer Letter, 82: 203-208. DOI: https://doi.org/10.1016/03043835(94)90013-2

Sridhar M, Thammaiah V and Suganthi RU (2016). Evaluation of carvacrol in ameliorating aflatoxin induced changes with reference to growth and oxidative stress in broiler chickens. Animal Nutrition and Feed Technology, 16: 283-296. DOIt: http://dx.doi.org/10.5958/0974-181X.2016.00024.X
Strasser A, Carra M, Ghareeb K, Awar W and Bohm J (2013). Protective effects of antioxidants on deoxynivalenol induced damage in murine lymphoma cells. Mycotoxin Research, 29: 203-208. DOI: https://doi.org/10.1007/s12550-013-0170-2

Streit E, Gerd S, Panagiotis T, Eleni T, Daniela M, Ionelia T, Cristina T, Anca N, Iuliana A, Olivier P and Isabelle PO (2012). Current situation of mycotoxin contamination and co-occurrence in animal feed-focus on Europe. Toxins (Basel), 4: 788-809. DOI: https://doi.org/10.3390/toxins4100788

Suttajit M 1998. Prevention and Control of Mycotoxins. in Proc. Mycotoxin Prevention and Control in Food grains, Semple R, L., Frio A. S, Hicks P, A, and Lozare J. V, eds., UNDP/FAO Regional Network Intercountry Cooperation on Preharvest Technology and Quality Control of Foodgrains, Bankok, Tailand,

Talebi E, Khademi M and Rastad A (2011). An over review on effect of aflatoxin in animal husbandry. Asian Journal of Experimental and Biological Sciences, 2: 754-757. Available at: https://pdfs.semanticscholar.org/31eb/5439737c5eaf05482383b389a 830bf568a78.pdf

Xue CY, Wang GH, Chen F, Zhang XB and Cao YC (2010). Immunopathological effects of ochratoxin A and T-2 toxin combination on broilers. Poultry Science, 89: 1162-1166. DOI: https://doi.org/10.3382/ps.2009-00609

Yang J, Zhang M and Zhou Y (2019). Effects of selenium-enriched Bacillus sp. compounds on growth performance, antioxidant status, and lipid parameters breast meat quality of Chinese Huainan partridge chicks in winter cold stress. Lipids in Health and Disease, 18:63. DOI: https://doi.org/10.1186/s12944-019-1015-6

Yunus AW, Nasir MK, Farooq U and Bohm J (2008). Prevalence of poultry diseases in district Chakwal and their interaction with mycotoxicosis: 1. Effects of age and flock size. Journal of Plant and Animal Science, 18: 107-113. Available at: http://agris.fao.org/agrissearch/search.do?recordID=PK2009000534

Yunus AW, Nasir MK, Farooq U, Aziz T and Bohm J (2009). Prevalence of poultry diseases in district Chakwal and their interaction with mycotoxicosis: 2. Effects of season and feed. Journal of Plant and Animal Science, 19:1-5. Available at: http://agris.fao.org/agrissearch/search.do?recordID=PK2010000149 